\title{
Common Vampire Bat (Desmodus rotundus) feeding on Lowland Tapir (Tapirus terrestris) in an Atlantic Forest remnant in southeastern Brazil
}

\author{
Ariana Pignaton Gnocchi ${ }^{1}$ \& Ana Carolina Srbek-Araujo ${ }^{1,2, *}$ \\ ${ }^{1}$ Universidade Vila Velha, Programa de Pós-Graduação em Ecologia de Ecossistemas, Laboratório de Ecologia e \\ Conservação de Biodiversidade, Rua Comissário José Dantas de Melo, $n^{\circ}$ 21, Boa Vista, \\ CEP 29102-920, Vila Velha, ES, Brazil \\ ${ }^{2}$ Instituto SerraDiCal de Pesquisa e Conservação, Belo Horizonte, MG, Brazil \\ *Corresponding Author: Dr.Ana Carolina Srbek-Araujo,email:srbekaraujo@hotmail.com
}

GNOCCHI, A. P., SRBEK-ARAUJO, A. C. Common Vampire Bat (Desmodus rotundus) feeding on Lowland Tapir (Tapirus terrestris) in an Atlantic Forest remnant in southeastern Brazil. Biota Neotropica. 17(3): e20170326. http:// dx.doi.org/10.1590/1676-0611-BN-2017-0326

\begin{abstract}
There are few studies on the diet of Common Vampire Bat (Desmodus rotundus), despite its wide geographic distribution. The species is considered exclusively hematophagous, and medium and large-sized mammals are their main prey. In this study we report evidences of Common Vampire Bat feeding on Lowland Tapir (Tapirus terrestris) in a protected area located in the north of the state of Espírito Santo, southeastern Brazil, from camera trap records. The bat tried to access the Lowland Tapir by the posterior dorsolateral side of the body, and used the mean stratum of the vegetation as a point of support and observation between the consecutive offensives on the prey. In the same reserve, there were also two events of bat offensives on domesticated ox (Bos sp.). But in these cases the attacks occurred from the scapular region of the prey. The record here reported represents the first documented attack of Desmodus rotundus on Tapirus terrestris in the Brazilian Atlantic Forest and one of the first records in the South America as a whole. Previous records were in the Pantanal (Brazil) and in the Amazon rainforest (Ecuador). The feeding on wild and domestic prey by Desmodus rotundus in the same locality may favor the transmission of rabies to populations of wild mammals, as well as to domestic animals, and may represent an economic and public health issue with negative effects also for wildlife.
\end{abstract}

Keywords: camera trap, Chiroptera, hematophagy, micro predator, Sooretama Biological Reserve.

\section{Predação de antas (Tapirus terrestris) por morcegos vampiros (Desmodus rotundus) em área de Mata Atlântica no sudeste do Brasil}

Resumo: Apesar de sua ampla distribuição geográfica, pouco se conhece sobre a dieta do morcego vampiro (Desmodus rotundus). A espécie é considerada exclusivamente hematófaga, sendo os mamíferos de médio e grande porte suas principais presas. O presente trabalho apresenta evidências de predação de antas (Tapirus terrestris) por morcegos vampiros a partir de registros obtidos por armadilhas fotográficas em uma área protegida localizada no norte do estado do Espírito Santo, sudeste do Brasil. A partir dos registros fotográficos obtidos, foi possível observar que o morcego tentou acessar a anta pela parte dorsolateral posterior do corpo, utilizando o estrato médio da vegetação como ponto de apoio e observação entre as consecutivas investidas sobre a presa. Na mesma área, também foram registrados dois eventos de investida de morcegos sobre boi-doméstico (Bos sp.), mas, nestes casos, os ataques ocorreram a partir da região escapular da presa. O registro obtido representa o primeiro registro documentado de ataque de Desmodus rotundus sobre anta na Mata Atlântica brasileira e um dos primeiros na América do Sul de forma geral, havendo registros anteriores no Pantanal (Brasil) e na Floresta Amazônica (Equador). Ressalta-se que a utilização de presas silvestres e domésticas por Desmodus rotundus em uma mesma localidade pode favorecer a transmissão de raiva para populações de mamíferos silvestres, bem como para os rebanhos e outras espécies domésticas, podendo vir a representar um problema econômico e de saúde pública com efeitos negativos também sobre as espécies silvestres.

Palavras-chaves: armadilha fotográfica, Chiroptera, hematofagia, micropredação, Reserva Biológica de Sooretama. 


\section{Introduction}

The Common Vampire Bat, Desmodus rotundus (É. Geoffroy, 1810) (Chiroptera, Phyllostomidae, Desmodontinae), is endemic to Latin America and is widely distributed, occurring from Mexico to central Argentina and Uruguay (Eisenberg \& Redford 1999). It can be found in all Brazilian territory (Reis et al. 2013). Bats of this species roost in places of difficult access and form relatively small colonies, ranging from 10 to 200 specimens (Mayen 2003). Studies carried out in the Amazon region indicated Desmodus rotundus is not abundant, both in terra firme and in várzea forests (Bobrowiec et al. 2014), although the species is more frequently recorded in villages (Bobrowiec 2012). These areas would represent important foraging areas for Common Vampire Bats, where they would feed mainly on domestic animals, although human attacks may also occur (Bobrowiec 2012). Thus, when there are farms or villages near the areas where the Common Vampire Bats occur, the populations of Desmodus rotundus tend to increase due to the great availability of food (Bobrowiec et al. 2015).

There are few studies on the diet of Desmodus rotundus, despite its wide geographic distribution. Since the first report of Desmodus rotundus feeding, based on direct observations made by Charles Darwin in Chile (Darwin 1839), diverse techniques have been employed by researchers, including molecular (Bobrowiec et al. 2015) and isotopic analyzes (e.g. Voigt \& Kelm 2006, Voigt et al. 2012, Streicker \& Allgeier 2016), in addition to the camera traps (e.g. Castellanos \& Banegas 2015, Galetti et al. 2016). Even with these methodological advances, the available records of diet of Common Vampire Bat are isolated and mainly from the western portion of South America (see discussion for details). It is known that this species is exclusively hematophagous and that its main prey are wild medium and large-sized mammals (Greenhall 1988). Common Vampire Bats use visual, acoustic and olfactory sensory abilities (Joermann et al. 1988) and infrared imaging pit organs (Campbell et al. 2002) to detect their potential prey, so they may also usually feed on livestock, horses, mules, goats, sheep, swine, and domestic birds (e.g. Delpietro et al. 1994 , Bobrowiec 2012, Bobrowiec et al. 2015). These animals are frequently grouped in rural properties, being easily detected by Common Vampire Bats (Delpietro et al. 1994).

Here we report evidences of Common Vampire Bats feeding on Lowland Tapir, Tapirus terrestris (Linnaeus, 1758) (Perissodactyla, Tapiridae), in a protected area located in the north of the state of Espírito Santo, southeastern Brazil, from camera trap records.

\section{Material and Methods}

The records were obtained at Sooretama Biological Reserve (Reserva Biológica de Sooretama - RBS; $18^{\circ} 53^{\prime}$ and $19^{\circ} 55^{\prime} \mathrm{S}, 39^{\circ} 55^{\prime}$ and $40^{\circ} 15^{\prime} \mathrm{W}$; $24,250 \mathrm{ha}$ ), located in the northern portion of the state of Espírito Santo, covering territories of Sooretama, Vila Valério, Jaguaré and Linhares municipalities. The RBS, together with the Vale Natural Reserve (Reserva Natural Vale - RNV; 22.711 ha), the Recanto das Antas Private Natural Heritage Reserve (Reserva Particular do Patrimônio Natural - RPPN Recanto das Antas) (221 ha) and the RPPN Mutum-Preto (379 ha), forms the largest continuous block of native vegetation in Espírito Santo, called Linhares-Sooretama Block (Srbek-Araujo et al. 2015). These reserves account for approximately 50,000 ha, representing more than $10 \%$ of the remaining forest area in the state (based on data available in FSOSMA \& INPE 2014).

The Linhares-Sooretama Block is composed by a mosaic of habitats, in which the dense lowland forest (Tabuleiro forest) predominates (Jesus $\&$ Rolim 2005). This forest is interspersed with várzea forests, less dense forest on sandy soils (Mussununga) and occasional native grassland (Campo nativo) (Jesus \& Rolim 2005, Kierulff et al. 2014). The climate in the region is tropical with dry winter, type Aw, according to Köppen classification (Alvares et al. 2014). The mean annual temperature in the region is $24.3^{\circ} \mathrm{C}$, ranging between maximums around $30^{\circ} \mathrm{C}$ and minimum of $19^{\circ} \mathrm{C}$ (Kierulff et al. 2014). The average annual rainfall is around $1,214 \mathrm{~mm}$, and the relative humidity of air is $84 \%$ (Kierulff et al. 2014). The Linhares-Sooretama Block is surrounded mainly by pastures, agricultural crops (especially fruit and coffee), and eucalyptus plantations.

The records were obtained by Bushnell Trophy Cam HD Aggressor digital camera traps (Bushnell Inc., Overland Park, USA). The camera traps were installed on 15 sampling points distributed along internal unpaved roads and in the forested interior of RBS and RNV. The camera traps were operated 24 hours a day. For each occasion of capture, a video (10 seconds duration) and two photographs were taken. The delay between consecutive records was set to 10 seconds. Camera traps were in place from October 2015 to August 2016, totaling 2,461 camera-days (for details on the calculation of the sampling effort, see Srbek-Araujo \& Chiarello 2005).

\section{Results and Discussion}

Records evidencing the attempted predation of Lowland Tapir by Common Vampire Bats were obtained on November 17, 2015, at a sampling point located circa $30 \mathrm{~m}$ from Barra das Abóboras Road, close to the northern limit of RBS (18 $59^{\prime} \mathrm{S}$ and $\left.40^{\circ} 02^{\prime} \mathrm{W}\right)$. The feed attempts began at 02:04 $\mathrm{h}$ and followed for approximately three minutes, until 02:07 h. According to the sequence of videos and photographic records (six sets of records as a whole), the bat makes several attempts of attack, accessing the tapir by the posterior dorsolateral side of the body. Among the consecutive offensives on the prey, the bat rests on tree trunks with small diameter, in the middle layer of the vegetation, and wait for the best moment to make new attacks (Figure 1). During the record-keeping period, the Common Vampire Bat attempted to land on the posterior dorsolateral side of the tapir at least three times, all of them unsuccessful, and an aborted landing on the prey was also recorded. The tapir seems to notice the touch of the bat on all landing attempts and turns quickly to the side (Video 1).

On December 12, 2015, two other events of attempted predation by Desmodus rotundus were obtained at RBS, but on these occasions the attempts were on domesticated ox, Bos sp. (Linnaeus, 1758). The two events were obtained at the same sampling point, located at Barra das Abóboras Road, at the northern boundary of RBS (18 $58^{\prime}$ 'S e $40^{\circ} 06^{\prime} \mathrm{W}$ ). Due to the proximity to pasture areas, which surrounding the reserve (neighboring properties), it is not uncommon to record domestic cattle on this road. Records were obtained between 21:30 h and 21:31 h (two consecutive videos and respective photos) and at 23:57 $\mathrm{h}$ (one set of records). The two events were on the same individual. On these occasions, at least two bats

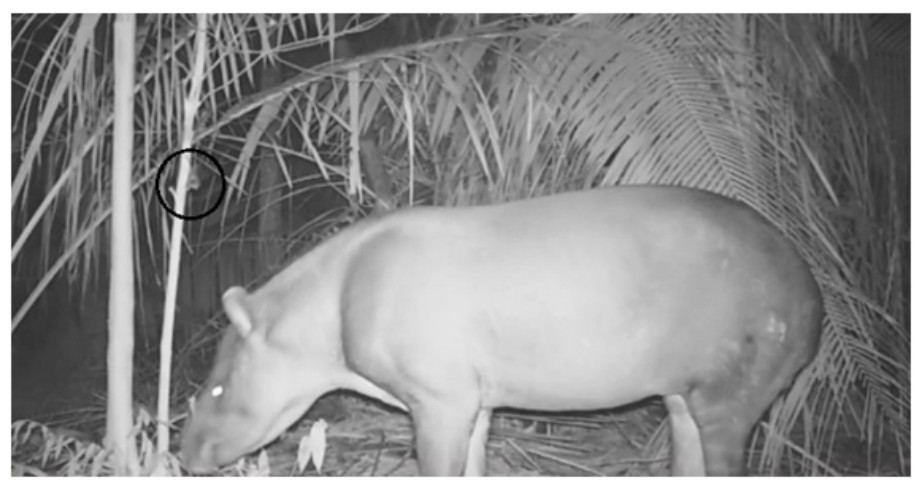

Figure 1. Common Vampire Bat (Desmodus rotundus) perched on tree trunk after one of the attempted attacks on Lowland Tapir (Tapirus terrestris) at Sooretama Biological Reserve, Espírito Santo state, southeastern Brazil. 
were observed simultaneously attacking the animal (Figure 2; Video 2). The attacks, with four offensives in the first event, occurred on the anterior part of the ox's body, near the scapular region, different from the attack observed on the tapir.

The record here reported represents the first documented record of Desmodus rotundus attack on Tapirus terrestris in the Brazilian Atlantic Forest. Previous records of Lowland Tapir predation by Common Vampire Bats in Brazil were obtained in the Pantanal (Galetti et al. 2016). There is also a record obtained in Ecuador (Amazon rainforest), in the region of the Yasuni National Park, where a bat was observed on the scapular region of a tapir (Castellanos \& Banegas 2015). In these two studies, the records were also obtained from camera traps. Predation records of Desmodus rotundus on other wild mammals are still known, such as the South American Sea Lions, Otaria flavescens (Shaw, 1800), on islands along the coast of Peru (Catenazzi \& Donelly 2008); the South American Red Brocket, Mazama americana (Erxleben, 1777), in the Atlantic Forest and in the Pantanal (Galetti et al. 2016); and the White-tailed Deer, Odocoileus virginianus (Zimmermann, 1780), in the El Platanal tropical forest, located in the Sierra Gorda Biosphere Reserve in Mexico (Sanchez-Cordero et al. 2011). Common Vampire Bats feed on invasive wild feral pigs (Sus scrofa Linnaeus, 1758) in the Atlantic Forest and in the Pantanal (Galetti et al. 2016). There are also reports of attacks on goats, cows and domestic pigs on farms in Argentina (Delpietro et al. 1994) and in different locations in the Amazon region, including attacks on domestic dogs (e.g. Bobrowiec 2012, Bobrowiec et al. 2015). Attacks on domestic pigs were also observed in the Atlantic Forest (Galetti et al. 2016). Records of predation of Desmodus rotundus on avian species are rare. There are records of attack on juvenile Humboldt Penguins (Spheniscus humboldti Meyen, 1834), in Pan de Azucar island in Chile (Luna-Jorquera \& Culik 1995), and on chickens in Amazonia (e.g. Bobrowiec 2012, Bobrowiec et al. 2015).

To avoid predation, hematophagous bats exhibit cryptic foraging behavior, hunting their prey preferentially on darkest hours of the night (Flores-Crespo et al. 1974) and/or on darker nights (Delpietro et al. 1994). This behavior is corroborated by that recorded on the present study. According to the moon phase's calendar, the moon was in its New Moon phase on the days when our records were obtained.

The attacks on domesticated ox, in which at least two bats were observed, may constitute a typical hunting strategy of Common Vampire Bats (Greenhall 1971). According to Greenhall (1971), haematophagous bats usually hunt in groups of 2-6 individuals, and these groups live inside the colonies as a social structure. In our recorded cases, both the tapir and the domesticated ox, bats accessed their prey from the dorsal part of the body, although in distinct specific regions, similar to that observed in other records of attacks on medium and large sized mammals (e.g. Sanchez-

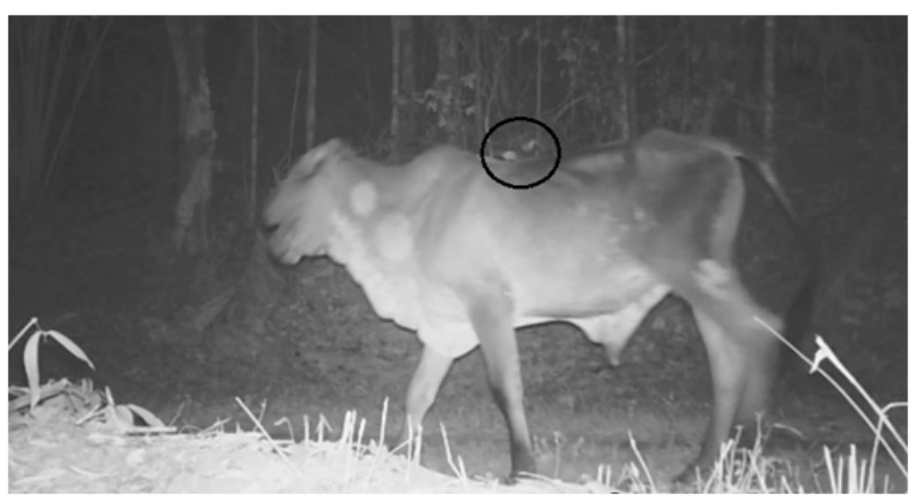

Figure 2. Two Common Vampire Bats (Desmodus rotundus) attacking a domesticated ox (Bos sp.) inside the Sooretama Biological Reserve, Espírito Santo state, southeastern Brazil.
Cordero et al. 2011, Castellanos \& Banegas 2015, Galetti et al. 2016). It may characterize the typical attack strategy of Desmodus rotundus when the prey are moving. On the other hand, when feeding on South American Sea Lions, the prey were lying on the ground and the Common Vampire Bats were observed feeding on the neck and on the flipper of individuals (Catenazzi \& Donelly 2008). In a resting domestic pig, the Common Vampire Bats feed on the ear of the prey (Galetti et al. 2016).

Similarly to the behavior observed in the present study, the perception of the approach of the bats resulting in sudden movements to avoid predation was also registered in South American Red Brocket in the Atlantic Forest (Galetti et al. 2016). In both cases, bats tried to access the prey by the posterior dorsolateral side of the body resulting on unsuccessful attacks. It may suggest a lower attack efficiency performed by Desmodus rotundus attacking the posterior dorsal part of wild prey.

Only three independent records (more than 1 hour interval between records of the same species for each sampling point) of predation by Common Vampire Bats were obtained in the Linhares-Sooretama Block from a total of 1,087 independent nocturnal records of mammals. By analyzing only Lowland Tapir records, 191 independent nocturnal records of the species were obtained, resulting in a $0.5 \%$ predator-prey encounter rate recorded by camera traps (1 independent record of predation). For the domestic ox, only four independent nocturnal records were obtained, resulting in a $50 \%$ predator-prey encounter rate ( 2 independent records of predation). These values may indicate a preference in feeding on domestic prey by Desmodus rotundus even inside protected areas. The consumption of blood of wildlife species may decline in areas where the availability of livestock is greater (Streicker \& Allgeier 2016). In these areas, cattle may become the main food source of Desmodus rotundus (Streicker \& Allgeier 2016), with a high degree of preference for cows in some sites (Voigt \& Kelm 2006). In the study developed by Galetti et al. (2016), the chances of a tapir being attacked by a Common Vampire Bat was estimated at $11 \%$ in the Pantanal. Although there is no abundance data available for Desmodus rotundus in the Linhares-Sooretama Block, the difference in rate of attack of tapirs between the two studies may indicate that the density of Common Vampire Bat in our study area is lower than in the region studied by Galetti et al. (2016).

The Common Vampire Bats can become infected with the rabies virus, which can lodge in the salivary glands of bats, allowing the transmission of the disease through its bite (Mayen 2003). Rabies can cause the death of wild mammals, including carnivores and ungulates (e.g. MacDonald 1993, Bengis et al. 2008), and domestic species, leading to heavy economic losses as result of herd infection and death of livestock (Almeida et al. 2008). We highlighted that diseases transmitted between wild and domestic species can be bidirectional, as in the case of rabies, and may be fatal for both groups and with potential for transmission to humans (Bengis et al. 2008). In this way, the potential transmission of rabies to humans and domestic animals, whether through the bite of infected bats or from the bite of sick domestic animals (especially domestic dog and domestic cat), can result in public health problems, mainly in rural areas and more isolated human villages. For this reason, it is important to maintain the vaccination of cattle and other domestic animals in areas subject to the presence of Common Vampire Bats, both for domestic animal welfare and for the protection and conservation of wildlife. In addition, it can be done the vaccinating of Desmodus rotundus against rabies applying a paste mixed with oral vaccine on the back of captured animals to indirectly protect other bats from the same colony (Almeida et al. 2008). The Lowland Tapir is classified as Vulnerable to extinction at global level (IUCN 2016) and in Brazilian territory (Ministério do Meio Ambiente 2014), and as Endangered in the state of Espírito Santo, where the species is restricted to a small number of protected areas (Chiarello et al. 2007, Flesher \& Gatti 2010). It makes the 
contamination of the remaining populations of Lowland Tapir with rabies virus even more serious, particularly in Espírito Santo.

The records reported in the present study reinforce that camera traps may assist in obtaining sporadic records of predation by Common Vampire Bats, thus contributing to the investigation of their prey in natural habitat. The record here reported represents one of the first documented cases of Desmodus rotundus attack on Tapirus terrestris in Brazil and in South America as a whole, with previous records only in the Brazilian Pantanal and in the Ecuadorian Amazon. The feeding on wild and domestic prey by Desmodus rotundus in the same locality, as observed in the present study, may favor the transmission of rabies to populations of wild mammals, as well as to domestic species, and may represent an economic and public health issue with negative effects also for wildlife.

\section{Supplementary material}

The following online material is available for this article:

Video 1: Common Vampire Bat (Desmodus rotundus) attacking a Lowland Tapir (Tapirus terrestris) at Sooretama Biological Reserve, Espírito Santo state, southeastern Brazil.

Video 2: Two Common Vampire Bats (Desmodus rotundus) attacking a domesticated ox (Bos sp.) at Sooretama Biological Reserve, Espírito Santo state, southeastern Brazil.

\section{Acknowledgments}

APG is grateful to the Coordenação de Aperfeiçoamento de Pessoal de Nível Superior (CAPES) for the postgraduate scholarship. ACSA tanks to Universidade Vila Velha and Fundação de Amparo à Pesquisa do Espírito Santo (FAPES 0607/2015), which sponsored the research of the Laboratorio de Ecologia e Conservação de Biodiversidade (LECBio). The authors would like to thank anonymous reviewers for suggestions and comments.

\section{Author Contributions}

Ariana Pignaton Gnocchi: Analysis of camera trap records (photos and video) and preparation of the manuscript. Ana Carolina Srbek-Araujo: Camera trapping (data collection), analysis of camera trap records (photos and video), preparation of the manuscript and manuscript translation.

\section{Conflicts of interest}

The authors declare no conflict of interest.

\section{References}

ALMEIDA, M.F., MARTORELLI, L.F.A., AIRES, C.C., BARROS, R.F. \& MASSAD, E. 2008. Vaccinating the vampire bat Desmodus rotundus against rabies. Virus Res. 137:275-277.

ALVAREZ, C.A., STAPE, J.L., SENTELHAS, P.C., GONÇALVES, J.L.M. \& SPAROVEK, G. 2014. Köppen's climate classification map for Brazil. Meteorol. Z. 22(6):711-728.

BENGIS, R.G., KOCK, R.A. \& FISCHER, J. 2002. Infectious animal diseases: the wildlife/livestock interface. Scientific and Technical Rev. - Off. Int. Epizoot. 21(1):53-65.

BOBROWIEC, P.E.D., LEMES, M.R. \& GRIBEL, R. 2015. Prey preference of the common vampire bat (Desmodus rotundus, Chiroptera) using molecular analysis. J. Mammal. 96(1):54-63.

BOBROWIEC, P.E.D., ROSA, L.S., GAZARINI, J. \& HAUGAASEN, T. 2014. Phyllostomid bat assemblage structure in Amazonian flooded and unflooded forests. Biotropica 46(3):312-321.

BOBROWIEC, P.E.D. 2012. A Chiroptera preliminary survey in the middle Madeira River region of Central Amazonia, Brazil. Mammalia 76:277-283.
CAMPBELL, A.L., NAIK, R.R., SOWARDS, L. \& STONE, M.O. 2002. Biological infrared imaging and sensing. Micron 33:211-225.

CASTELLANOS, A.X. \& BANEGAS, G.A. 2015. Vampire bats bite lowland tapirs in Yasuni National Park, Ecuador. Tapir Conservation 24(33):7.

CATENAZZI, A. \& DONELLY, M.A. 2008. Sea lion Otaria flavescens as host of the common vampire bat Desmodus rotundus. Mar. Ecol-Prog. Ser. 360:285-289.

CHIARELLO, A.G., COSTA, L.P., LEITE, Y.L.R., PASSAMANI, M., SICILIANO, S. \& ZORTÉA, M. 2007. Os Mamíferos Ameaçados de Extinção no Estado do Espírito Santo. In Espécies da fauna ameaçadas de extinção no estado do Espírito Santo (M. Passamani \& S.L. Mendes, eds). Instituto de Pesquisas da Mata Atlântica, Vitória, p.29-45.

DARWIN, C.R. 1839. The zoology of the voyage of H.M.S. Beagle. Part 2: Mammalia. By George R. Waterhouse. Edited and superintended by Charles Darwin. Smith Elder and Co., London.

DELPIETRO, H., KONOLSAISEN, F., MARCHEVSKY, N. \& RUSSO, G. 1994. Domestic cat predation on vampire bats (Desmodus rotundus) while foraging on goats, pigs, cows and human beings. Appl. Anim. Behav. Sci. 39:141-150.

EISENBERG, J.F. \& REDFORD, K.H. 1999. Mammals of the Neotropics. Volume 3: Ecuador, Peru, Bolivia, Brazil. The University of Chicago Press, Chicago and London.

FLESHER, K.M. \& GATTI, A. 2010. Tapirus terrestris in Espírito Santo, Brazil. Tapir Conservation 19/1(26):16-23.

FLORES CRESPO, R., LINHART, S.B., BURNS, R.J. \& MITCHELL, G.C. 1972. Foraging behavior of the common vampire bat related to moon light. J. Mammal. 53:366-368.

FSOSMA \& INPE. 2014. Atlas dos Remanescentes Florestais da Mata Atlântica - Período 2012-2013. São Paulo, Fundação SOS Mata Atlântica \& Instituto Nacional de Pesquisas Espaciais. 61p. https://www.sosma.org.br/wp-content/ uploads/2014/05/atlas_2012-2013_relatorio_tecnico_20141.pdf, (last access on 23/11/2014).

GALETTI, M., PEDROSA, F., KEUROGHLIAN, A. \& SAZIMA, I. 2016. Liquid lunch - vampire bats feed on invasive feral pigs and other ungulates. Front. Ecol. Environ. 14:505-506.

GREENHALL, A.M .1971. Control of vampire bats. Study and program project for Latin. America. Bol. Oficina Sanit. Panam. 71:231-246.

GREENHALL, A.M .1988. Feeding behavior. In: GREENHALLA.M, SCHMIDT, U. (eds) Natural history of vampire bats, pp 111-132. CRC Press, Boca Raton, FL.

IUCN. 2016. The IUCN Red List of Threatened Species. Version 2016-1. International Union for Conservation of Nature and Natural Resources, Cambridge.

JESUS, R.M. \& ROLIM, S.G. 2005. Fitossociologia da Mata Atlântica. Boletim Técnico da Sociedade de Investigações Florestais 19:1-149.

JOERMANN, G., SCHMIDT, U. \& SCHMIDT, C. 1988. The mode of orientation during flight and approach to landing in two Phyllostomid bats. Ethology 78:332-340.

KIERULFF, M.C.M., AVELAR, L.H.S., FERREIRA, M.E.S., POVOA, K.F. \& BÉRNILS, R.S. 2014. Reserva Natural Vale: história e aspectos físicos. Ciência \& Ambiente 49:7-40.

LUNA-JORQUERA, G. \& CULIK, B.M. 1995. Penguins bled by vampires. J Ornithol 136:471-472.

MACDONALD, D.W. 1993. Rabies and wildlife: a conservation problem? Onderstepoort Vet. Res. 60:351-355.

MAYEN, F. 2003. Haematophagous bats in Brazil, their role in rabies transmission, impact on public health, livestock industry and alternatives to an indiscriminate reduction of bat population. J. Vet. Med. B 50:469-472.

MIALHE, P.J. 2013. Preferential prey selection by Desmodus rotundus (E. Geoffroy, 1810, Chiroptera, Phyllostomidae) feeding on domestic herbivores in the municipality of São Pedro - SP. Braz. J. Biol. 74(3):579-584.

MINISTÉRIO DO MEIO AMBIENTE. 2014. Lista Nacional Oficial de Espécies da Fauna Ameaçada de Extinção. Portaria no 444, de 17 de dezembro de 2014 Diário Oficial da União 245, Brasília.

REIS, N.R., FREGONEZI, M.N., PERACCHI, A.L. \& SHIBATTA, O.A. 2013 Morcegos do Brasil: Guia de Campo. Technical Books Editora, Rio de Janeiro. 
SANCHÉS-CORDEIRO, V., BOTELLO, F., MANGAÑA-COTA, G. \& IGLESIAS, J. 2011. Vampire bats, Desmodus rotundus, feeding on white-tailed deer, Odocoileus virginianus. Mammalia 75:91-92.

SRBEK-ARAUJO, A.C. \& CHIARELLO, A.G. 2005. Is camera-trapping an efficient method for surveying mammals in Neotropical forests? A case study in south-eastern Brazil. J. Trop. Ecol. 21(1):121-125.

SRBEK-ARAUJO, A.C., MENDES, S.L. \& CHIARELlO, A.G. 2015. Jaguar (Panthera onca Linnaeus, 1758) roadkill in Brazilian Atlantic Forest and implications for species conservation. Braz. J. Biol. 75(3):581-586.

STREICKER, D.G. \& ALLGEIER, J.E. 2016. Foraging choices of vampire bats in diverse landscapes: potential implications for land-use change and disease transmission. J. Appl. Ecol. 53:1280-1288.
VOIGT, C.C., VOIGT-HEUCKE, S.L. \& SCHNEEBERGER, K. 2012. Isotopic data do not support food sharing within large networks of female vampire bats (Desmodus rotundus). Ethology 118:260-268.

VOIGT, C.C. \& KELM, D.H. 2006. Host preference of the common vampire bat (Desmodus rotundus; Chiroptera) assessed by stable isotopes. J. Mammal. 87:1-6.

Received: 24/01/2017

Revised: 04/04/2017

Accepted: 28/06/2017

Published online: 24/07/2017 